\title{
Investigating Pre-Service English Teachers' Stages of Concern Toward Using Wiki
}

\section{İngilizce Öğretmen Adaylarının Wiki Kullanımına Yönelik Kaygı Așamalarının İncelenmesi}

\author{
Halil KAYADUMAN*, Ömer DELİALİOĞLU**
}

\begin{abstract}
Concern Based Adaption Model (CBAM) was used as the theoretical framework for examining the Stages of Concerns of English Language pre-service teachers regarding the use of a Wiki for English as Foreign Language (EFL) classes. Stages of concern are used as a measure for adaptation of new technologies to instruction. Learning by Design (LBD) instructional method was implemented for three weeks in the context of an undergraduate course, "Approaches to English Language Teaching", in the department of Foreign Language Education. A single group pretest-posttest design was used where the Stages of Concern Questionnaire (SoCQ) of 14 pre-service teachers were measured and analyzed. Results of the Wilcoxon Signed Rank test showed that there was statistically significant difference between the Consequence and Collaboration concerns pre and post-test scores. However, the analysis showed no statistically significant difference in the Unconcerned, Informational, Personal, Management, and Refocusing stages of the pre-service teachers.
\end{abstract}

Keywords: Stages of concern, English language pre-service teachers, wiki, technology integration

Öz: Hizmet öncesi İngilizce öğretmen adaylarının, İngilizce öğretiminde Wiki kullanımına dönük Kayg1 Aşamalarını inceleme için kavramsal çerçeve olarak Kaygı Tabanlı Adaptasyon Modeli (KTAM) kullanılmıştır. Kaygı aşamaları yeni teknolojilerin öğretime uyarlanmasında ölçüm amaçlı kullanılmaktadır. Tasarlayarak Öğrenme öğretim yöntemi Yabancı Diller bölümünde, "İngilizce Dili Öğretiminde Yaklaşımlar” lisans dersi kapsamında 3 hafta süreyle uygulanmıştır. Çalışma kapsamında tek grup ön-test son-test araştırma modeli kullanılmıştır. Araştırmaya katılan 14 öğretmen adayının Kayg1 Aşamaları verileri, ön-test son-test şeklinde Kaygı Aşamaları anket formu ile toplanmıştır. Wilcoxon testi sonuçlarına göre, İngilizce öğretmen adaylarının Sonuç ve İşbirliği kaygı aşamalarında anlamlı farklılıklar bulunmasına rağmen; Farkındalık, Bilgi, Kişisel, Yönetim ve Yeniden Odaklanma kaygı aşamalarında anlamlı bir farklılık bulunamamıştır.

Anahtar Kelimeler: Kaygı aşamaları, hizmet öncesi İngilizce öğretmenleri, wiki, teknoloji entegrasyonu

\section{Introduction}

The rapid increase in using information technologies in society and personal life of people has also affected educational areas. In the literature, one can find several articles related to the advantages of using information technologies in educational settings. Besides other benefits, it is stated that these technologies can be especially useful for improving students' learning, motivation, and higher order thinking skills (Collins \& Halverson, 2009; Godfrey, 2001).

Considering the benefits of using information technologies for the sake of educational aims, several technology integration projects have been conducted across the world. Three large-scale projects were: The Preparing Tomorrow's Teachers to Use Technology in the United States, National Basic Education Program, and Movement of Enhancing Opportunities and Improving Technology (FATIH-Fırsatları Artırma ve Teknolojiyi İyileştirme Hareketi) in Turkey (USDE, 2004 as cited in Mims et al., 2006; MoNE, 2007; MoNE, 2013). States allocated a large amount of resources to these projects to make use of the advantages of latest technologies in the enhancement of educational settings.

\footnotetext{
*Res. Asst., Middle East Technical University, Faculty of Education, Ankara, Turkey, e-mail: halilk@ metu.edu.tr **Assoc. Prof. Dr., Middle East Technical University, Faculty of Education, Ankara, Turkey, e-mail: omerd@metu.edu.tr
} 
Although there are several opportunities available for teachers, various factors, internal and external, still affect teachers' decisions about the adaptation of technologies to instruction and their teaching (Oncu, Delialioglu, \& Brown, 2008). When sought to the literature, it could be seen how teachers currently use some of the popular technologies for educational purposes. Most frequently, teachers use technologies for low-level routines, such as preparing notes, entering grades, and doing administrational works rather than facilitating learning and improving performances of teachers and students (Kurt, 2012; Karaca, 2011; Dawson, 2008). Developing new skills so that teachers, both in-service and pre-service, can adopt technologies into instructional activities for enhancing learning became even more important. Yang and Huang (2008) expressed that technology integration necessitates changes for teachers. Therefore, teachers need to involve in a change process to develop the necessary skills for integrating technology. Casey and Rakes (2002) stated that people may show resistance to the change as a nature of human because change brings the unknown. Rogers (2003) reported that people who confronted with an innovation would indicate reluctance to using it before accepting it. This unknown or uncertainty can cause to arouse some concerns and doubts. Concern can be described as "the composite representations of feelings, preoccupations, thoughts and consideration given to a particular issue or task" (Hall \& George, 1979, 8). Hall, George and Rutherford (1977) stated that concerns change when teachers become expert about using innovations. At this point, the question is how to provide interventions on technology integration to involve teachers in the change process and resolve their concerns and doubts so as to ensure successful usage of technology for educational purposes.

The present study focused on examining the Stages of Concerns (SoC) of English Language pre-service teachers in regard to using a Web 2.0 tool, i.e. Wiki, for EFL teaching before and after conducting Learning by Design (LBD) instructional approach. SoC is one of the important components of Concern based Adoption Model (CBAM) and was used as the theoretical framework in the current study. SoC provides sets of concerns which come out during the change process, which was used to evaluate the effect of the instruction for technology integration. Hall and Hord (2014) pointed out that understanding SoC of teachers can result in designing, developing and implementing more effective and relevant interventions. Koehler and Mishra (2005) pointed out for LBD that "this framework attempts to capture some of the essential qualities of teacher knowledge required for technology integration in pedagogy" (p. 95). Research studies where LBD approach was used had positive results on teachers' technology integration (Mishra \& Koehler, 2006; Alayyar, 2011).

The findings of the current study contribute to the design and development of instructions for successful technology integration in EFL classes. In addition, the findings provide valuable information for principals, administrators, teachers and practitioners working on successful interventions for technology integration.

\section{Literature Review}

Teachers' concerns have been of interest since the 1960s. France Fuller was one of the leading researchers who studied and described the concerns of teachers. She carried out several research studies related to the concerns of pre-service and in-service teachers in regard to educational change. Concern Based Adoption Model (CBAM) was established based on Fuller's works. CBAM proposes sets of concerns which emerge in the process of change. These concerns change when teachers become advanced users in making use of the innovations (Hall, George \& Rutherford, 1977). CBAM has three dimensions and SoC is one of the most important dimension of it. The stages of $\mathrm{SoC}$ are given as Unconcerned, Informational, Personal, Management, Consequence, Collaboration, and Refocusing. Descriptions of these seven stages are (Hall \& Hord, 2014);

- Stage 0-Unconcerned: Teachers have little concern or involvement with the innovation

- Stage 1-Informational: Teachers have general awareness of the innovation and interested in learning more about innovation 
- Stage 2- Personal: Teachers have doubts about the demands of the innovation on themselves.

- Stage 3-Management: Teachers' concerns shift to the process and tasks about using the innovation.

- Stage 4-Consequence: Teachers have considerations about the impact of the innovation on the students.

- Stage 5- Collaboration: Teachers have concerns about collaboration with others about using the innovation

- Stage 6- Refocusing: Teachers have concerns about exploring the more universal benefits of innovation, and enhancing the usage.

In the literature, there are different kinds of studies which state the importance of SoC. Yang and Huang (2008) pointed out that developing the higher level of SoC should be done for the sake of successful integration. Hollingshead (2009) said that seven SoC should be aroused and resolved to help teachers learn to use innovation in a more advanced way. Similarly, Hall and Hord (2014) recommended resolving self and task concerns and arousing the impact concerns of SoC. Although the importance of SoC is stated in the literature, it is rare to find studies which supply instructional approaches or guidelines to change them. Casey and Rakes (2002) examined the effect of technology training on teachers' concerns related to instructional technology. Findings of their study revealed that Management, Consequence and Collaboration stages had strong relationships with technology integration training. Unconcerned, Informational, Personal and Refocusing stages had no significant correlation with training. In addition, they found that the time engaged with the innovation was effective on teachers' comfort level and effective usage. Chen (1999) examined the type of innovation-decision (authority versus optional decision), and type of intervention (concern based versus non-concern based) on arousing educators' concern related to using the Internet for educational purposes. The results of the study showed that authority decision was more effective than optional decision and concern based interventions were more effective than non-concern based interventions. Liu, Theodore, and Lavelle (2004) investigated an online graduate course on K12 in-service teachers' concerns about technological treatments for instruction. Results of the study indicated that there was a significant increase in all seven SoC between pre- and posttests.

Wiki is one of the online collaborative tools by which people can write, edit or revise pages. The related literature indicates that Wiki can provide some advantages to educational settings. Keith (2006) pointed out that people could work collaboratively, discuss and learn from others with the help of Wiki. Lamb (2004) expressed that Wiki could increase the awareness of process learning rather than focusing on outcomes of learning. In the study of Chang and Schallert (2005), Wiki was used for English language classes in high school. The study found that using Wiki for teaching the English language developed the writing skills of students and students could give and take instant feedbacks from each other. Considering these advantages, Wiki were targeted to integrate into EFL classes in the current study.

Learning by Design (LBD) was used in the present study to integrate Wiki into EFL classes. Han and Bhattacharya (2001) stated that LBD focuses on design process which provides a rich context for learning to occur. Learners engage in ill-structured problems by constructing their knowledge. They stated that LBD puts emphasis on both process and outcome of the learning. Fessakis, Tatsis and Dimitracopoulou (2008) pointed out that LBD can help teachers propose high-quality learning experiences for their students. Vreman-de Olde and de Jong and Gijlers (2013) compared the LBD assignments to traditional instruction. They found that the students in LBD activities had better conceptual knowledge than the traditional classroom. Johnson (2012) explained that LBD offers various opportunities to foster an attitudinal change of pre-service teachers' technology usage. In addition to these studies, it was stated that LBD can provide many opportunities for integrating technology into educational environments (Koehler \& Mishra, 2005; Mishra \& Koehler, 2006; Alayyar, 2011). Therefore, providing 
opportunities by the help of the LBD instructional approach may facilitate the pre-service teachers' technology integration process and contribute to understand the reasons behind their concerns in this process. Therefore, this study was grounded on LBD to increase the possibility of integrating Wiki into EFL classes.

In that regard, the purpose of the present study is to investigate the changes occurred on SoC of English Language pre-service teachers in regard to LBD activities implemented in the context of "Approaches to English Language Teaching" course. The current study extended the examination of English language pre-service teachers' SoC toward the use of one of Web 2.0 tools, Wiki. In so doing, the present study can help gain insights about the concerns of the preservice teachers related to the implementation of technology integration activities, especially on LBD instructional approach. This can facilitate the process of designing and developing more relevant courses and interventions in teacher education institutions. In addition, revealing the possible concerns of English language pre-service teachers may promote technology integration planning to prepare the pre-service teachers for successful technology integration.

\section{Method}

Single group pre-test and post-test design (Fraenkel, Wallen, and Hyun, 2012) was used to see the effect of the LBD instructional approach on pre-service teachers' SoC. Using purposive sampling, the present study targeted the specific population of English language pre-service teachers. Babbie (2001) pointed out that it is appropriate to use purposive sampling depending on the knowledge and characteristics of the target group and the aims of the research. The context of the study was an undergraduate course in the department of Foreign Language Education of a public university in 2014 fall semester. The course "Approaches in English Language Teaching" was offered to undergraduate students. As part of the course, learning by design based instructional interventions was conducted during the last three weeks of the semester to integrate Wiki into EFL classes. The participants of the present study consisted of 14 English language pre-service teachers who were in their second year. Out of 14 participants, 12 were female and 2 were male pre-service teachers. All of the participants were able to use computer and familiar with using Web 2.0 tools such as Facebook, Twitter, Moodle, Blogger, etc. The demographic information of pre-service teachers is presented in Table 4 and 5 in the result section. Fourteen of the pre-service teachers voluntarily participated in the study. Following research question and sub-questions guided the current study.

1. Is there a significant difference in Stages of Concerns of English Language pre-service teachers regarding the use of Wiki in their English as Foreign Language (EFL) classes when they are exposed to Learning by Design (LBD) instructional approach?

1.1. Is there a significant difference in Unconcerned stage of English Language preservice teachers regarding the use of Wiki in their EFL classes when they are exposed to LBD instructional approach?

1.2. Is there a significant difference in Informational stage of English Language preservice teachers regarding the use of Wiki in their EFL classes when they are exposed to LBD instructional approach?

1.3. Is there a significant difference in Personal stage of English Language pre-service teachers regarding the use of Wiki in their EFL classes when they are exposed to LBD instructional approach?

1.4. Is there a significant difference in Management stage of English Language preservice teachers regarding the use of Wiki in their EFL classes when they are exposed to LBD instructional approach?

1.5. Is there a significant difference in Consequence stage of English Language preservice teachers regarding the use of Wiki in their EFL classes when they are exposed to LBD instructional approach?

1.6. Is there a significant difference in Collaboration stage of English Language preservice teachers regarding the use of Wiki in their EFL classes when they are exposed to LBD instructional approach? 
1.7. Is there a significant difference in Refocusing stage of English Language preservice teachers regarding the use of Wiki in their EFL classes when they are exposed to LBD instructional approach?

The dependent variable was Stages of Concern and the independent variable was the Learning by Design instruction for EFL.

\section{Collection Instrument}

The participants were measured before and after the LBD instructional approach for their concern levels using the Stages of Concern Questionnaire (SoCQ) (George et al., 2006). The questionnaire had 35 items and participants were requested to choose how much they agreed with the statement on a Likert scale from 0 to 7 . The highest score indicated that participants think of an item to be "7-very true of me now" and the lowest score indicated " 0 -not relevant". The values of coefficients of internal reliability ranged from 0.64 for Stage 0 to 0.83 for Stage 2, with six of the seven coefficients being above 0.70 . The values of test-retest correlations range from 0.65 for Stage 0 to 0.86 for Stage 1, with four of the seven correlations above 0.80 . Considering the internal reliability of Stage 0, George et al. (2006) explained that the results of the factor analysis grouped several items under this stage, which express a lack of knowledge or interest about innovation. Hence, this stage has not been extracted from the original questionnaire, although its internal reliability does not match the criteria of minimum .70 (Büyüköztürk, 2009). See the Table 1 and 2 for coefficients of internal reliability for $S o C Q$ and test-re-test correlations on $S o C Q$.

Table 1. Coefficients of Internal Reliability for SoCQ

\begin{tabular}{|c|c|c|c|c|c|c|c|}
\hline Stage & 0 & 1 & 2 & 3 & 4 & 5 & 6 \\
\hline $\begin{array}{l}\text { Alpha- } \\
\text { Original } \\
\text { Questionnaire }\end{array}$ & .64 & .78 & .83 & .75 & .76 & .82 & .71 \\
\hline $\begin{array}{l}\text { Alpha- } \\
\text { Current } \\
\text { Study }\end{array}$ & .42 & .80 & .72 & .52 & .73 & .76 & .53 \\
\hline
\end{tabular}

(George et al., 2006, p. 20)

Table 2. Test-Retest Correlations on SoCQ

\begin{tabular}{llllllll}
\hline Stage & 0 & 1 & 2 & 3 & 4 & 5 & 6 \\
\hline Alpha & .65 & .86 & .82 & .81 & .76 & .84 & .71 \\
\hline
\end{tabular}

(George et al., 2006, p. 20)

The reliability of the present study was calculated by the help of Cronbach alpha value as well. Pre-test scores of pre-service teachers were used to calculate the value. The values of coefficients of internal reliability ranged from 0.42 to 0.80 , with four of the seven coefficients being above 0.70 . Field (2009) states that the reliability depends on the sample size of the study. Since there was a small sample size which included only 14 participants, it might have revealed the results. On the other hand, the overall reliability of the scale in the present study was found 0.87 which indicates a reliable scale. Therefore, it could be concluded that the scale was reliable in the present study.

\section{Procedures}

Learning by Design (LBD) instruction was carried out in three weeks where the $S o C Q$ was administered as pre-test and post-test to the same group of pre-service teachers. Following instructional interventions and corresponding teaching methods were utilized in the scope of the LBD. Before starting the intervention, pre-service teachers were asked to fill the $S o C Q$. 
Week-1: Introduction to Technology Integration in Education: The first week of the instruction began with a presentation on the definition of technology and types of technology, explaining transparent and emerging technologies. Existing and emerging technologies were compared using the descriptions of the two technology types. The possible benefits of using technologies were grouped into four as effectiveness, efficiency, pace and costs. The definition and main features of Web 2.0 tools were explained and research studies focusing on the use of these tools in education were shared with the pre-service teachers. A classroom discussion was administered with following guiding questions:

- Do we need to adapt and use technologies in education?

- How can technologies facilitate teaching and learning process?

After the discussion, Wiki and its usage areas were explained. Examples of the use of Wiki tools for different instructional purposes were shown.

Week 2: Exploration of Wiki Environment: The second week of the LBD based instruction started with activities to explore the Wiki tool. The pre-service teachers experienced the Wiki environment. The followings are the activities: (i) Registering to the Wiki web2.0 tool and exploring its writing, editing or revising pages features. (ii) Demonstrating how Wiki pages are developed and sharing example Wiki. (iii) Designing and creating personal Wiki pages and contributing to others' pages. (iv) Searching for instructional methods and teaching strategies that could be supported with Wiki.

Week 3: Designing a Lesson Plan: During the third and last week, 2 or 3 pre-service teachers in each group collaboratively designed and developed EFL lesson plans through group-work where Wiki was integrated. Exploration and discussion activities were conducted on the lesson plans that outlined how Wiki could be used to support teaching-learning activities. After completing the lesson plans and the activities, participants were asked to re-take the $S o C Q$, their answers were used as the post-test data.

By following the LBD based instructional practices summarized in Table 3, it was aimed to degrade the self and task concerns of English pre-service teachers while increasing the impact concerns of them (Hall and Hord, 2014).

Table 3. Instructional Strategies to Target SoC

Weeks Instructional Strategies

\section{-Presentation}

1. Week: Introduction to Technology -Question and Answers

Integration in Education -Discussion

-Demonstration

2. Week: Exploration of Wiki Environment -Collaboration

-Hands-on Learning

-Exploration

3. Week: Designing A Lesson Plan -Investigation

-Design

\section{Results}

Data collected through the SoCQ was analyzed for each stage of concern in the CBAM. Wilcoxon Signed Rank test was applied to compare the scores between pre-tests and post-tests in terms of SoC. Wilcoxon Signed Rank test is non-parametric techniques which are used for 
repeated measures. It is alternative to parametric repeated measures t-test. The reason behind using non-parametric techniques in this study is because sample size consists of 14 English language pre-service teachers (Pallant, 2007).

The results of the experience of pre-service teachers about using Web 2.0 tools are presented in Table 4 . Of all pre-service teachers, 5 pre-service teachers $(35.7 \%)$ have been using Web 2.0 tools for 2 years, 3 pre-service teachers (21.4\%) have been using Web 2.0 tools for 1 years, 3 pre-service teachers $(21.4 \%)$ have been using Web 2.0 tools for 5 years or more, 2 preservice teachers $(14.3 \%)$ have been using Web 2.0 tools for 4 years and 1 pre-service teacher (7.1\%) have been using Web 2.0 tools for 3 years. All in all, it could be understood that all preservice teachers are familiar with using at least one of Web 2.0 tools.

Table 4. Experience of Using At Least One of the Web 2.0 Tools

\begin{tabular}{lll}
\hline Time & $f$ & Percent \\
\hline Never & 0 & 0 \\
1 Year & 3 & 21.4 \\
2 Years & 5 & 35.7 \\
3 Years & 1 & 7.1 \\
4 Years & 2 & 14.3 \\
5 Years or more & 3 & 21.4 \\
\hline
\end{tabular}

Pre-service teachers expressed their level of use of Web 2.0 tools as stated in Table 5. According to the results; $11(78.6 \%)$ of them perceived as "Old hand", 2 (14.3\%) of them perceived as "Past user" and only $1(7.1 \%)$ of them perceived as "Intermediate". Although most of the pre-service teachers' experiences are around 2 years, they mostly perceived themselves as "Old Hand User" as seen in Table 5.

Table 5. Level of Use of Web 2.0 Tools Perceived by English Language Pre-service Teachers

\begin{tabular}{lcc} 
Level of Use & $f$ & Percent \\
\hline Non-User & 0 & 0 \\
Novice & 0 & 0 \\
Intermediate & 1 & 7.1 \\
Old Hand User & 11 & 78.6 \\
Past User & 2 & 14.3 \\
\hline
\end{tabular}

The descriptive data and the Wilcoxon Signed Rank test results were summarized in Table 6. Wilcoxon Signed Rank test indicated that post-test ranks of "Consequence" concern were statistically significantly higher than pre-test ranks, $\mathrm{Z}=-2.17, \mathrm{p}=.03$. Similarly, Wilcoxon Signed Rank test indicated that post-test ranks of "Collaboration" concern were statistically significantly higher than pre-test ranks, $\mathrm{Z}=-2.10, \mathrm{p}=.03$. 
Table 6. Descriptive Information and Wilcoxon Test Results of Pre and Post Tests

\begin{tabular}{|c|c|c|c|c|c|c|c|}
\hline & \multicolumn{2}{|c|}{ Pre-tests } & \multicolumn{2}{|c|}{ Post-Tests } & \multirow[b]{2}{*}{$d f$} & \multirow[b]{2}{*}{$Z$} & \multirow[b]{2}{*}{$p$} \\
\hline & $M$ & $S D$ & $M$ & $S D$ & & & \\
\hline Stage 0- Unconcerned & 17.07 & 5.65 & 17.07 & 5.44 & 13 & -.30 & 0.97 \\
\hline Stage 1- Informational & 18.85 & 7.43 & 23.57 & 5.33 & 13 & -1.72 & 0.08 \\
\hline Stage 2- Personal & 19.85 & 7.31 & 25.21 & 6.04 & 13 & -1.98 & 0.05 \\
\hline Stage 3-Management & 16.35 & 5.93 & 18.21 & 5.68 & 13 & -1.00 & 0.31 \\
\hline *Stage 4- Consequence & 20.50 & 6.17 & 23.92 & 5.39 & 13 & -2.17 & $0.03 *$ \\
\hline *Stage 5-Collaboration & 13.15 & 6.92 & 21.64 & 8.45 & 13 & -2.10 & $0.03^{*}$ \\
\hline Stage 6- Refocusing & 19.07 & 4.93 & 23.00 & 3.88 & 13 & -1.98 & 0.05 \\
\hline
\end{tabular}

On the other hand, Wilcoxon Signed Rank test indicated that post-test ranks of "Unconcerned" $(Z=-.30, p=.97)$, "Informational" $(Z=-1.72, p=.08)$, "Personal" $(Z=-1.98, p=.05)$, "Management" $(\mathrm{Z}=-1.00, \mathrm{p}=.31)$, and "Refocusing" $(\mathrm{Z}=-1.98, \mathrm{p}=.05)$ concerns were not statistically significantly higher than their pre-test ranks. Although p-value of "Personal" and "Refocusing" concerns equal to .05 , they were not considered as statistically significant due to the non-parametric test that conducted. That's because Pallant (2007) pointed out that nonparametric tests are less powerful than parametric tests.

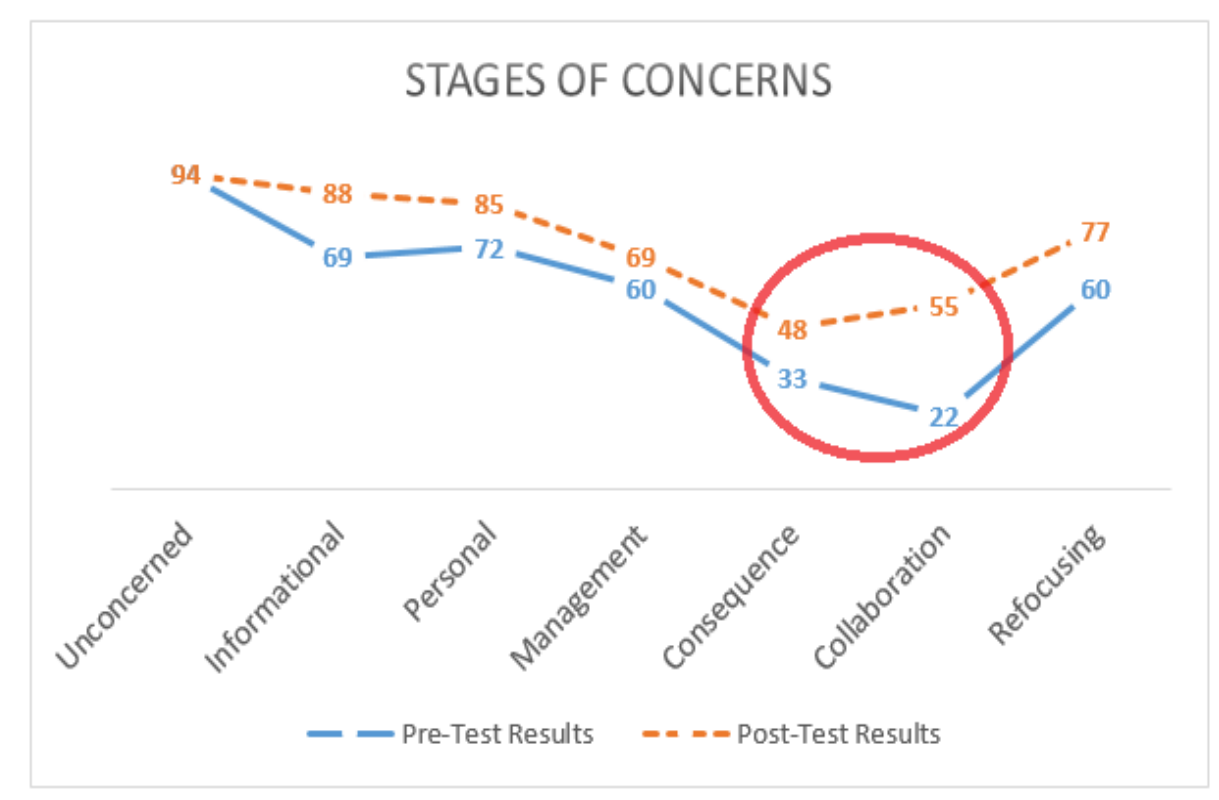

Figure 1. Stages of Concerns of Pre-service Teachers' Percentile Scores (Group Profiles)

The group percentile scores of pre-service teachers were presented in Figure-1. It could be concluded that considerations of pre-service teachers about the impact of using Wiki on the students in English as Foreign Language (EFL) classes and concerns which state collaboration efforts with others about using Wiki in education are increased by the help of Learning by Design (LBD) instruction carried out in three weeks. On the other hand, they have still selfdoubts about themselves how to integrate and manage Wiki in EFL classes. In addition, their considerations about enhancing the usage of Wiki in EFL classes did not change after these 3 weeks intervention. An interesting finding of the present study was that there was an increase in all concern stages scores as seen in Figure-1. However, when looking at inference, only the increases were in Consequence and Collaboration stages scores. 


\section{Discussion}

The purpose of the present study was to investigate SoC of English language pre-service teachers about integrating Wiki into EFL classes before and after conducting learning by design instructional approach. Although all scores of seven stages were increased in post-tests, only two stages were found statistically significant. There was statistically significant change on Consequence and Collaboration concern stages. On the other hand, there was no statistically significant difference between pre-tests and post-tests in terms of Unconcerned, Informational, Personal, Management, and Refocusing stages.

Pre-tests results provided information about pre-service teachers' initial concerns. As illustrated in Figure-1, their initial concerns mostly are around of Unconcerned, Informational and Personal which are self-concerns. It could be understood that pre-service teachers have selfdoubts about themselves or they have a lack of interest and information about using Wiki in EFL classes. Hall and Hord (2014) explained that people will have moments of self-doubts about using the innovation even if enough support and promising tools were provided to them. Hence, it could be said that having self-doubts about using Wiki was common among preservice teachers at first.

After three weeks instruction, all concern stages increased, as illustrated in Figure-1, however; statistically significant differences were found on Consequence and Collaboration concern stages. Although pre-service teachers' self-doubts, lack of interest or knowledge about using Wiki remained statistically unchanged, their considerations in regard to the impact of using Wiki on the students and collaborating with others about the integration of Wiki significantly increased. In other words, Learning by Design instruction helped pre-service teachers arouse Consequence and Collaboration concerns. This may stem from the activities carried out in the context of LBD instruction (Han and Bhattacharya, 2001; Fessakis et al., 2008; Vreman-de Olde et al., 2013). When pre-service teachers involved in exploration, collaboration and design activities throughout three weeks, their Consequence and Collaboration concerns might have arisen notably. Hall et al. (1977) stressed that SoC changes when people become more proficient in using the innovations. These results might be the indication of the progress of pre-service teachers about using Wiki in EFL classes.

On the other hand, Unconcerned, Informational, Personal, Management and Refocusing concern stages did not change significantly and remained as they are in the pre-test scores. It can be understood that pre-service teachers still have a lack of interest and knowledge, and are uncertain about their sufficiency to integrate Wiki. At this point, George et al. (2006) underlined that solely having more information about innovation or experiencing does not ensure that initial concerns will resolve and later concerns will emerge. They also stated that emergence and resolution of the concerns are very personal and necessitates cognitive and affective factors in the interventions. Therefore, the reasons behind the concern stages should be investigated so that English language pre-service teachers could be helped for their self and management concerns.

There are similar research studies related to concern stages. Casey and Rakes (2002), found out that technology integration training had a correlation with Management, Consequence and Collaboration stages. In the present study, Consequence and Collaboration concerns came out to be effected by the treatment but Management concerns did not change significantly. Liu et al., (2004) revealed that there was a significant increase in all seven stages after the online instruction. It consisted with the present study to some extent; all the concerns increased, but only Consequence and Collaboration were significant. At this point, George et al. (2006) also explained that $\mathrm{SoC}$ is a developmental movement, which means the users experience some of the concerns intensely at some time and then while those concerns subside, other concerns emerge.

The present study can help to gain understandings about the concerns of English language pre-service teachers related to the implementation of technology integration activities, especially on LBD instructional approach and thus, it can contribute to designing and developing more appropriate instructions for pre-service teachers. Although there are significant 
changes in Consequence and Collaboration concern stages, 5 concern stages were not affected by the treatment. Hall and Hord (2001) noted that resolving concerns can help people use the innovation in a more advanced way. At this juncture, this study can provide guideline not only for revising but also informing future research in similar conditions. In addition, the findings provide valuable information for principals, administrators, teachers and practitioners working on successful interventions for technology integration.

The generalization of the findings is limited by individual characteristics of pre-service teachers, small sample size and research methodology of the study because the present study has only 14 pre-service teachers and does not have a control group. In addition, it could be pointed out as another limitation that the study carried out in 3 weeks and separately from the course content. If the instruction had been conducted over a longer period and aligned with course content, the effects might have been different. Hence, preparing interventions in line with the course content and with a longer period may provide more appropriate learning experiences for pre-service teachers and accordingly their usage of innovation could be promoted.

Further research studies are needed because there are limitations of the present study. The present study can be extended to other settings with larger sample sizes. Random sampling procedures can overcome limited generalization of the findings. In addition, this research could be improved by carrying out other research methodologies.

\section{References}

Alayyar, G. M. (2011). Developing pre-service teacher competencies for ICT integration through design teams. Unpublished doctoral dissertation. University of Twente, Enschede, Netherlands.

Babbie, E. (2001). Practice of social research ( $9^{\text {th }}$ ed.). Belmont, CA: Wadsworth Thomson Learning.

Büyüköztürk, Ş. (2009). Sosyal bilimler için veri analizi el kitabı. Ankara: Pegem Akademi.

Casey, H. B., \& Rakes, G. C. (2002). An analysis of the influence of technology training on teacher stages of concern regarding the use of instructional technology in schools. Journal of Computing in Teacher Education, 18(4), 124-132.

Chang, Y., \& Schallert, D. L. (2005). The design for a collaborative system of English as foreign language composition writing of senior high school students in Taiwan. In Proceedings of the Fifth IEEE international Conference on Advanced learning Technologies (pp. 774-775).

Chen, M.-P. (1999). Prescribing interventions for internet novices based on stages of concern. Educational Media International, 36(4), 295-299.

Collins, A., \& Halverson, R. (2009). Rethinking education in the age of technology: The digital revolution and schooling in America. Teachers College Press.

Dawson, V. (2008). Use of information and communication technology by early career science teachers in Western Australia. International Journal of Science Education, 30(2), 203219.

Fessakis, G., Tatsis, K., \& Dimitracopoulou, A. (2008). Supporting "learning by design" activities using group blogs. Educational Technology \& Society, 11(4), 199-212.

Field, A. (2009). Discovering Statistics Using SPSS (3rd ed.). Sage Publications.

Fraenkel, J. R., Wallen, N. E., \& Hyun, H., H. (2012). How to design and evaluate research in education (8th ed.). New York, NY: McGraw-Hill.

George, A. A., Hall, G. E., \& Stiegelbauer, S. M. (2006). Measuring Implementation in Schools: The Stages of Concern Questionnaire. Austin, TX: SEDL.

Godfrey, C. (2001). Computers in school: Changing technologies. Australian Educational Computing, 16(2), 14-17.

Hall, G. E., \& George, A. A. (1979). Stages of concern about the innovation: The concept, initial verification and some implications. Retrieved May 10, 2014, from http://www.eric.ed.gov/contentdelivery/servlet/ERICServlet?accno=ED187716 
Hall, G. E., George, A. A., \& Rutherford, W. L. (1977). Measuring stages of concern about the innovation: a manual for the use of the soc questionnaire. Retrieved May 10, 2014, from http://www.eric.ed.gov/contentdelivery/servlet/ERICServlet?accno=ED147342

Hall, G. E., \& Hord, S. M. (2001). Implementing change: patterns, principles, and potholes. Boston: Pearson/Allyn \& Bacon.

Hall, G. E., \& Hord, S. M. (2014). Implementing change: patterns, principles, and potholes. (4th ed.). Pearson.

Han, S., \& Bhattacharya, K. (2001). Constructionism, learning by design, and project based learning. In M. Orey (Ed.), Emerging perspectives on learning, teaching, and technology. Retrieved February 17, from http://epltt.coe.uga.edu/

Hollingshead, B. (2009). The concerns-based adoption model: a framework for examining implementation of a character education program. NASSP Bulletin, 93(3), 166-183. doi:10.1177/0192636509357932

Johnson, L. D. (2012). The effect of design teams on preservice teachers' technology integration. Unpublished doctoral dissertation. Syracuse University.

Karaca, F. (2011). Factors associated with technology integration to elementary school settings: a path model. Unpublished doctoral dissertation. Middle East Technical University, Ankara, Turkey.

Keith, M. (2006). Wiki and student writing. Teacher Librarian, 34(2), 70-72.

Koehler, M. J., \& Mishra, P. (2005). Teachers learning technology by design. Journal of Computing Teacher Education, 21(3), 94-102.

Kurt, S. (2012). Examining teachers' use of computer-based technologies: A case study. Education and Information Technologies, 18(4), 557-570. Doi: 10.1007/s10639-0129199-7.

Lamb, B. (2004). Wide open spaces: Wiki, ready or not. EDUCAUSE Review, 39(5), 36-48.

Liu, Y., Theodore, P., \& Lavelle, E. (2004). A preliminary study of the impact of online instruction on teachers' technology concerns. British Journal of Educational Technology, 35(3), 377-379.

Mims, C., Polly, D., Shepherd, C., \& Inan, F. (2006). Examining PT3 projects designed to improve preservice education. Tech Trends, 50(3), 16-24.

Mishra, P., \& Koehler, M. J. (2006). Technological pedagogical content knowledge: A framework for teacher knowledge. Teachers College Record, 108(6), 1017-1054.

MoNE. (2007). BT Entegrasyonu Temel Arastirmasi. Retrieved July 21, 2013 from http://ocw.metu.edu.tr/pluginfile.php/3298/course/section/1180/BT\%20Entegrasyonu.p df

MoNE. (2013). Fatih Project. Retrieved July 21, 2013 from http://fatihprojesi.meb.gov.tr/tr/english.php

Oncu, S., Delialioglu, O., \& Brown, C. A. (2008). Critical components for technology integration: How do instructors make decisions? Journal of Computers in Mathematics and Science Teaching, 27(1), 19-46.

Pallant, J. (2007). SPSS survival manual (3rd ed.). New York, NY: McGraw-Hill Education.

Rogers, E. M. (2003). Diffusion of innovation (5th ed.). New York: Free Press.

Vreman-de Olde, C. G., De Jong, T., \& Gijlers, H. (2013). Learning by designing instruction in the context of simulation-based inquiry learning. Educational Technology and Society, 16(4), 47-58.

Yang, S. C., \& Huang, Y.-F. (2008). A study of high school English teachers' behavior, concerns and beliefs in integrating information technology into English instruction. Computers in Human Behavior, 24(3), 1085-1103. doi:10.1016/j.chb.2007.03.009 


\section{Uzun öz}

\section{Giriş}

Teknolojideki hızlı ilerlemeler insanların yaşantı alanlarını etkilediği gibi eğitim alanlarını da etkilemiştir. Literatürde, teknolojilerin eğitim alanlarında kullanıldığ 1 durumlarda ortaya çıkan pek çok fayda listelenmiştir. $\mathrm{Bu}$ faydalara örnek olarak, teknolojinin öğrencilerin motivasyonunu, öğrenmesini ve ileri düzey düşünme becerilerini geliştirdiği söylenmektedir (Collins ve Halverson, 2009; Godfrey, 2001).

Ülkelerin teknoloji entegrasyonu projelerine büyük miktarlarda yatırım yapmasıyla, eğitim ortamlarında teknoloji kullanım olanakları artmıştır (USDE, 2004 den aktaran Mims ve diğerleri, 2006; MoNE, 2007; MoNE, 2013). Bu teknoloji entegrasyonu projeleriyle öğretmenler için pek çok olanaklar sunulmasına rağmen, öğretmenlerin teknolojiyi kendi öğretimlerinde kullanması pek çok içsel ve dişsal faktör tarafindan belirlenmektedir (Oncu, Delialioglu ve Brown, 2008). Bu sebeple, bu faktörlerin iyileştirilerek öğretmen ve öğretmen adaylarının teknoloji entegrasyonu becerilerinin geliştirilmesi daha da önem kazanmaktadır. Yang ve Huang (2008) teknoloji entegrasyonun öğretmenler açısından bir değişim süreci gerektirdiğinden bahsetmişlerdir. Değişim bilinmezlik ve belirsizlik getireceği göz önünde bulundurulduğunda (Casey ve Rakes, 2002; Rogers, 2003), uygulayıcıların kaygılarının ve şüphelerinin ortaya çıkmasına sebep olabilir. Hall, George ve Rutherford (1977) öğretmenlerin kullandıkları yeniliklerde uzmanlaştıkça, kaygılarının değişeceğini iddia etmişlerdir. Bu noktada, problem nasıl eğitimler ve uygulamalar düzenlenmelidir ki, öğretmen ve öğretmen adayları kaygılarını aşarak, ileri seviye de teknolojiden eğitim ve öğretim amacıyla faydalanabilsinler.

$\mathrm{Bu}$ çalışma İngilizce öğretmen adaylarının teknolojiyi tasarlayarak öğrenme yaklaşımı kapsamında, Wiki Web 2.0 aracını kullanarak İngilizce dersi tasarlarken ortaya çıkan Kayg1 aşamalarını inceleme üzerine dayanmaktadır. Kaygı aşamaları, Kaygı tabanlı Adaptasyonu modelinin bir alt bileşenidir ve bu çalışmanın teorik alt yapısını oluşturmaktadır. Kaygı aşamaları değişim sürecinde ortaya çıkan 7 adet kaygı aşamasını tanımlamıştır ve bu çalışmada uygulanan öğretimin değerlendirilmesinde kullanılmıştır. Hall ve Hord (2014) değişim sürecinde yer alan kişilerin kaygı aşamalarını anlamanın, daha etkili ve verimli eğitimler ve uygulamalar tasarlanmasına ve geliştirilmesine yardımcı olacağını söylemiş̧lerdir. Bu sebeple bu çalışmanın bulguları İngilizce öğretiminde öğretmen adaylarının kaygılarını ortaya çıkarak daha etkili eğitimler ve ders içerikleri geliştirilmesine yardımcı olabilecektir.

$\mathrm{Bu}$ çalışmanın amacı teknolojiyi tasarlayarak öğrenme yaklaşımı aktiviteleriyle, Wiki, Web 2.0 aracını kullanarak İngilizce dersi tasarlayan, İngilizce öğretmen adaylarının bu kapsamda kaygı aşamalarında meydana gelen değişimleri incelemektir. $\mathrm{Bu}$ araştırmanın yapılması İngilizce öğretmen adaylarının teknoloji entegrasyon aktivitelerini uygularken ortaya çıkan kaygıları hakkında bize bilgiler sunabilecektir. Böylelikle, bu kaygıların göz önüne alınarak daha etkili ve verimli dersler ve uygulamaların yapılması konusunda yardımc1 olabilecektir. Ayrıca yeni politikalar ve teknoloji planlamaları yapılırken çalışmanın bulgularının göz önünde bulundurulması, teknoloji entegrasyonu projeleriyle hedeflenen amaçlara ulaşılmasını kolaylaştırabilir.

\section{Yöntem}

$\mathrm{Bu}$ çalışmada tek grup ön-test son-test araştırma modeli (Fraenkel, Wallen, ve Hyun, 2012) kullanılmıştır. Çalışma Türkiye' de bir devlet üniversitesinde Yabancı Diller Bölümü, "İngilizce Öğretiminde Yaklaşımlar” isimli lisans dersi kapsamında uygulanmıştır. Ders kapsamında teknolojiyi tasarlayarak öğrenme yaklaşımı dönemin son 3 haftasında uygulanmıştır. İlk hafta eğitimde teknoloji entegrasyonu ile ilgili bir giriş yapılarak bu konu hakkında sınıf içi tartışmalar düzenlenmiştir. Ayrıca teknolojinin eğitimde kullanıldığında sağlayacağı faydalara dair Google Doc Web 2.0 aracıyla bir örnek gösteri yapılmıştır. İkinci haftada, Wiki aracının özelliklerini inceleme, kullanma ve faydalarına dair araştırma yapma çalışmaları işbirliği 
şeklinde yürütülmüştür. Son haftada ise, öğrencilere ders planı tasarım şablonu verilerek, işbirlikçi bir şekilde Wiki entegre edilmiş bir ders planı tasarlanması istenmiştir.

Katılımcılar 12 kadın ve 2 erkekten oluşan, İngilizce öğretmenliği 2. sınıf öğrencilerdir. Çalışmaya katılan 14 öğretmen adayı, en az 1 yıl olmak üzere Web 2.0 araçlarıyla ilgili tecrübeleri olduklarını belirtmişlerdir. İngilizce öğretmen adayları uygulama başlamadan önce ve tamamlandıktan sonra Kaygı Aşamaları Anket formu (George, Hall ve Stiegelbauer, 2006) aracılığıyla iki defa ölçülmüştür. Çalışmanın araştırma sorusu aşağıdaki gibidir.

1. İngilizce öğretmen adayları teknolojiyi tasarlayarak öğrenme yaklaşımı kapsamında Wiki aracını kullanarak tasarladıkları ders planları sürecinde, kaygı aşamaları ön-test ve son-testleri arasında anlamlı bir farklılık var mıdır?

\section{Sonuç ve Tartışma}

Çalışma kapsamında toplanan ön ve son testler Wilcoxon Signed Rank testi araciliyla karşılaş̧ırılmıştır. Elde edilen sonuçlara göre; tüm kaygı aşamalarında yükselme meydana gelirken, sadece "Sonuç" ve "İşbirliği" kaygı aşamalarında istatistiksel olarak anlamlı farklılıklar ortaya çıkmıştır. Diğer kaygı aşamaları olan "Farkındalık", "Bilgi", "Kişisel", "Yönetim" ve "Yeniden Odaklanma" kaygı aşamalarında istatistiksel olarak anlamlı farklılıklar bulunmamıştır. Ön-test sonuçlarında, İngilizce öğretmen adaylarının kaygılarının daha çok kişisel kaygılar etrafında şekillendiği görülürken bu durum son-test sonuçlarında da değişmemiştir. Yani çalışmanın başında öğretmen adaylarının, Wiki aracının İngilizce ögretiminde kullanımına karşı ilgisiz ya da bilgisiz olma, bu aracı kullanarak bir İngilizce dersi yürütebilme yeterlilikleri ve süreci yönetme becerileri konusundaki kaygıları uygulamadan sonra da değişmemiştir. Bir diğer taraftan Wiki aracının kullanıldığ İngilizce öğretimi derslerinde ögrencilerin bu öğretimden nasıl etkileneceği ve Wiki araciyla ilgili olarak diğer kişilerle işbirliği yapma konularında olan kaygılarında anlamlı yükselmeler meydana gelmiştir. Öğretmen adayları teknolojiyi tasarlayarak öğrenme yaklaşımı kapsamında yaptıkları araştırma, işbirliği ve tasarım aktiviteleri, kaygılardaki bu değişimlere sebep olduğu söylenebilir. George, Hall ve Stiegelbauer (2006) kaygı aşamalarındaki oluşabilecek değişimleri kişisel olduğunu ve bu değişimlerde bilişsel ve duyuşsal faktörlerin önemli oranda etkili olduğunu söylemişlerdir. Bunlar göz önünde bulundurulduğunda 3 hafta süreyle "İngilizce Öğretiminde Yaklaşımlar" dersi kapsamında uygulanan teknolojiyi tasarlayarak öğrenme yaklaşımı aktivitelerinin geliştirilmesi gerektiği söylenebilir. Böylelikle İngilizce öğretmen adaylarının ileride uygulayacakları İngilizce öğretimi aktivitelerine Wiki Web 2.0 aracının entegre edilmesi süreci daha da kolaylaştırılabilir. 